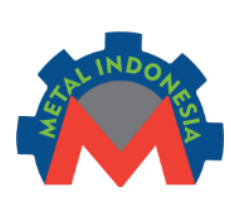

JMI Vol. 39 No. 2 Desember 2017

METAL INDONESIA

Journal homepage:

http://www.jurnalmetal.or.id/index.php/jmi

p-issn : $0126-3463$

e-issn : $2548-673 \mathrm{X}$

\title{
UJI BANDING ANTAR LABORATORIUM \\ UNTUK REFERENCE MULTIMETER DALAM MENJAMIN STANDAR MUTU LABORATORIUM KALIBRASI
}

\author{
INTER-LABORATORY COMPARISONS TEST \\ FOR MULTIMETER REFERENCE IN GUARANTEE \\ QUALITY STANDARD OF CALIBRATION LABORATORY
}

\author{
Muhammad Nauval Fauzi \\ Balai Besar Logam dan Mesin (BBLM), Kementerian Perindustrian \\ Jalan Sangkuriang No. 12 Bandung 40135- Indonesia \\ Email: nauval911@gmail.com; nauval@kemenperin.go.id
}

\begin{abstract}
Abstrak
Laboratorium kalibrasi Balai Besar Logam dan Mesin (BBLM) bersama dua laboratorium kalibrasi PT. Telkom, yaitu laboratorium kalibrasi Telkom Maintenance Service Center Area V Jawa Timur (MSC Surabaya) dan Area III Jawa Barat (MSC Cibinong) melakukan uji banding antar laboratorium menggunakan alat standar kalibrasi Reference Multimeter 8508A. Pengukuran dilakukan pada alat Reference Multimeter 8508A milik masing-masing peserta uji banding terhadap dua alat referensi yaitu Multiproduct Calibrator 5500A dan 5700A. Pengukuran ini bertujuan untuk melihat seberapa besar nilai angka kesalahan (error number $=E n$ ) yang didapatkan disetiap titik pengukuran pada beberapa besaran pengukuran. Titik pengukuran yang diambil yaitu $100 \mathrm{mV}, 10 \mathrm{~V}$ dan $700 \mathrm{~V}$ pada $D C$ dan $A C$ Voltage; $100 \mu \mathrm{A}, 100 \mathrm{~mA}$, dan 10 A pada $D C$ dan $A C$ Current; $1 \Omega, 100 \mathrm{~K} \Omega$ dan 10 $\mathrm{M} \Omega$ pada Resistance 2 wire dan $10 \Omega, 1 \mathrm{~K} \Omega$, dan $100 \mathrm{~K} \Omega$ pada Resistance 4 wire. Data pengukuran yang diverifikasi yaitu perhitungan nilai mean, standar deviasi dan nilai angka kesalahan (En). Apabila nilai $E n$ hasil perhitungan $-1 \leq E n \leq 1$ maka bisa disimpulkan bahwa pada titik pengukuran tersebut masih dalam kondisi setara, sedangkan apabila diluar $-1 \leq E n \leq 1$ maka dianggap tidak setara. Hasil uji banding ketiga laboratorium menunjukkan nilai $E n$ dalam kondisi setara untuk keseluruhan besaran dan titik pengukuran, kecuali pada titik pengukuran $10 \Omega$ pada Resistance 4 wire untuk Multiproduct Calibrator 5700A di kedua laboratorium kalibrasi Telkom.
\end{abstract}

Kata Kunci: uji banding, angka kesalahan (En), laboratorium kalibrasi, reference multimeter 8508A.

\begin{abstract}
Inter-comparison test in laboratory have been carried out by Balai Besar Logam dan Mesin calibration laboratory with two other calibration laboratories of PT. Telkom, which are Telkom Maintenance Service Center Division V East Java (MSC Surabaya) and Division III West Java (MSC Cibinong), using standard calibration tool Reference Multimeter 8508A. Measurements were carried out from Reference Multimeter 8508A with two other reference tools, Multiproduct Calibrator $5500 A$ and $5700 A$ to define the error number (En) from each measurement point. The measurement points are $100 \mathrm{mV}, 10 \mathrm{~V}$ and $700 \mathrm{~V}$ at DC Voltage and AC Voltage; $100 \mu \mathrm{A}, 100 \mathrm{~mA}$, and $10 \mathrm{~A}$ at DC Current and AC Current ; $1 \Omega, 100 \mathrm{~K} \Omega$ and $10 \mathrm{M} \Omega$ at resistance 2 wire ; and $10 \Omega, 1 \mathrm{~K} \Omega$ and $100 \mathrm{~K} \Omega$ at resistance 4 wire. Measurement data are verified, mean value are calculated, standard deviation and error number (En) are documented. If the value of En calculation are $-1 \leq E n \leq 1$ then it can be concluded that the measurement is still in equivalent condition, but if the value of En calculation are outside $-1 \leq E n \leq 1$ then the measurement considered unequal. The results of the three laboratory comparisons show the En value in equivalent condition for the whole quantity and the measurement point except at the point of measurement $10 \Omega$ at resistance 4 wire for Multiproduct Calibrator 5700A for both calibration laboratories of PT. Telkom.
\end{abstract}

Keywords: inter-comparison, error number (En), calibration laboratory, reference multimeter 8508A 


\section{PENDAHULUAN}

Indonesia saat ini memiliki sekurangkurangnya 246 laboratorium kalibrasi yang telah terakreditasi Komite Akreditasi Nasional - Badan Standarisasi Nasional (KAN-BSN). Sesuai dengan nomor urutan akreditasinya laboratorium kalibrasi memiliki nomor urut 001 atau LK 001 yang dimiliki laboratorium yang berada dilingkungan Kementerian Perindustrian yaitu laboratorium kalibrasi Balai Besar Logam dan Mesin (BBLM) Bandung, sementara untuk nomor urut 246 atau LK 246 IDN dimiliki oleh laboratorium kalibrasi PT. Enseval Medika Prima, Jakarta sebagai laboratorium kalibrasi yang terakhir terakreditasi saat ini. ${ }^{(9)}$

Setiap laboratorium kalibrasi yang telah terakreditasi wajib mempunyai sebuah standar yang nantinya akan digunakan sebagai dasar akreditasinya yang meliputi penerapan suatu persyaratan yang bersifat manajemen maupun penerapan persyaratan kompetensi teknis untuk jenis kalibrasi yang dilakukannya. Hal tersebut tercermin pula dalam klasul 4 dan klausul 5 ISO/IEC 17025. ${ }^{(2,6,10)}$

Dalam hal penerapan persyaratan kompetensi teknis, kompetensi suatu laboratorium kalibrasi dapat dinilai antara lain melalui ketersediaan personel teknis dengan kemampuan yang memadai sesuai dengan bidang kalibrasinya, penggunaan peralatan yang sesuai, terkalibrasi dan tertelusur ke satuan Standar Internasional (SI). Hal terpenting lainnya yaitu adanya suatu mekanisme yang dijalankan oleh laboratorium tersebut untuk dapat menjamin mutu hasil kalibrasi yang dilakukan. ${ }^{(7,8,17)}$

Ada beberapa cara dalam mengatasi hal tersebut, salah satunya adalah dengan berpartisipasi dalam kegiatan uji banding antar laboratorium. Hal tersebut merupakan kewajiban mutlak bagi laboratorium yang terakreditasi. Kegiatan uji banding dapat diselenggarakan oleh badan akreditasi terkait di suatu negara ataupun uji banding independen yang dilakukan antara sesama laboratorium kalibrasi yang telah terakreditasi lainnya. Kegiatan tersebut sebagai salah satu upaya untuk memantau kemampuan teknis laboratorium terakreditasi secara berkala sehingga dapat menjamin standar mutu laboratorium itu sendiri. ${ }^{(10,17)}$

Laboratorium kalibrasi Balai Besar Logam dan Mesin (BBLM) telah melakukan suatu kegiatan uji banding antar laboratorium bersama dua laboratorium kalibrasi yang dimiliki PT. Telekomunikasi Indonesia, Tbk (Telkom) yaitu laboratorium kalibrasi Telkom Maintenance Service Center Area V Jawa Timur (MSC Surabaya) dan Area III Jawa Barat (MSC Cibinong).

Uji banding ini menggunakan alat standar kalibrasi Reference Multimeter 8508A yang dimiliki semua peserta uji banding. Laboratorium kalibrasi Telkom MSC Surabaya telah ditentukan sebagai koordinator pelaksanaan dan tempat dilaksanakannya uji banding tersebut sesuai dengan keputusan yang telah disepakati sebelumnya.

Makalah ini merupakan hasil penelitian perbandingan terhadap performa alat kalibrasi Reference Multimeter 8508A dari masingmasing peserta uji banding dengan melakukan proses pengukuran terhadap Multiproduct Calibrator 5500A dan 5700A sebagai alat referensinya. Pengukuran ini bertujuan untuk melihat seberapa besar nilai angka kesalahan (error number $=E n)$ di setiap titik-titik pengukuran pada semua besaran pengukuran dari masing-masing peserta uji banding serta membandingkan nilai $E n$ yang didapat semua peserta uji banding tersebut satu dengan yang lainnya.

\section{TINJAUAN PUSTAKA}

Performansi atau kinerja sebuah laboratorium dapat diukur dengan cara melakukan kalibrasi internal untuk memenuhi standar mutu laboratorium yang baik dan benar seperti yang telah ditetapkan dalam International Standard Organization (ISO). Kompetensi suatu laboratorium dalam pengendalian mutu internal dapat pula diimplementasikan dengan cara ikut serta dalam program uji profisiensi atau kegiatan uji banding antar laboratorium. Hal tersebut sangatlah sejalan dengan apa yang 
terkandung dalam prinsip-prinsip SNI ISO/IEC 17025: 2008. ${ }^{(2,8,10)}$

Kegiatan uji banding antar laboratorium selain dapat dimanfaatkan untuk mendapatkan evaluasi unjuk kerja dalam memelihara standar mutu laboratorium kalibrasinya. Hasil uji banding tersebut sangatlah diperlukan juga dalam memenuhi persyaratan akreditasi laboratorium sesuai SNI ISO/IEC 17025: 2008 bagi semua laboratorium yang belum terakreditasi. ${ }^{(2,6,10)}$

Nilai perbandingan dari uji banding yang dilakukan dilihat dari hasil perhitungan nilai En yang didapatkan disetiap titik-titik pengukuran dan nilai ketidakpastian yang didapatkan pada saat pengukuran itu dilakukan. Nilai En yang didapatkan disetiap titik-titik pengukuran mempunyai nilai lebih kecil atau sama dengan -1 dan/lebih besar atau sama dengan 1, atau biasa dituliskan dengan $-1 \leq E n \leq 1{ }^{(8,17)}$

Sesuai prosedur yang telah ditetapkan oleh $I S O$, sekiranya apabila nilai yang didapatkan tidak sesuai nilai $-1 \leq E n \leq 1$, maka evaluasi terhadap alat kalibrasi perlu dilakukan atau dilakukan investigasi lebih lanjut untuk mencari sumber kesalahan yang terjadi. ${ }^{(8,17)}$

Kesalahan dapat terjadi pada tahap pelaksanaan proses kalibrasi maupun pada tahap pengolahan dan analisa data. Nilai dari ketidakpastian dalam proses kalibrasi atau pengukuran suatu alat ukur juga menjadi salah satu ukuran keberhasilan dari kegiatan uji banding antar laboratorium. ${ }^{(2,7,16)}$

Reference Multimeter 8508A seperti pada Gambar 1 merupakan suatu alat standar 8.5 digit yang berfungsi hanya mengukur (measure). Alat ini dapat memberikan hasil yang sangat akurat dan lebih stabil tanpa memerlukan pembacaan atau pengukuran lain dari luar 'self calibration'. $(3,4,11)$

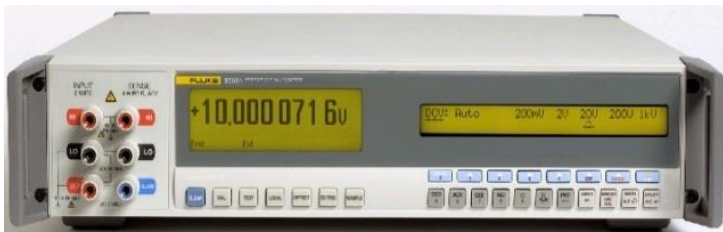

Gambar 1. Reference Multimeter 8508A

Pada umumnya, 8508A ini di fungsikan sebagai alat standar utama pada sebuah laboratorium kalibrasi dikarenakan alat tersebut memiliki akurasi yang sangat baik serta memiliki kemampuan pengukurannya hingga 8.5 digit. 8508A dapat pula digunakan sebagai kalibrator untuk mengkalibrasi alat standar lain dibawahnya seperti Multiproduct Calibrator 5500A, 5520A dan Multiproduct Calibrator 5700A serta masih banyak lagi peralatan standar lainnya. ${ }^{(3,4,11)}$

Multiproduct Calibrator 5500A dan 5700A merupakan salah satu alat standar yang sering digunakan dalam proses kalibrasi untuk pengukuran beberapa besaran listrik. Pada Multiproduct Calibrator 5500A seperti Gambar 2 mempunyai dua fungsi utama yaitu dapat berfungsi sebagai sumber (source) dan dapat pula berfungsi sebagai alat ukur (measure). ${ }^{(3,4,11)}$

Adapun fungsi 5500A sebagai sumber untuk beberapa besaran pengukuran antara lain : untuk tegangan $a c / d c$ ( $a c / d c$ voltage), arus $a c / d c$ (ac/dc current), tahanan 2/4 kabel (resistance 2/4 wire), volt/div dan time/div pada osciloscope serta besaran pengukuran temperature untuk semua tipe pada termokopel (thermocouple). Sedangkan yang berfungsi sebagai measure, hanya dapat mengukur untuk besaran pengukuran temperatur saja. ${ }^{(3,4,5,11)}$

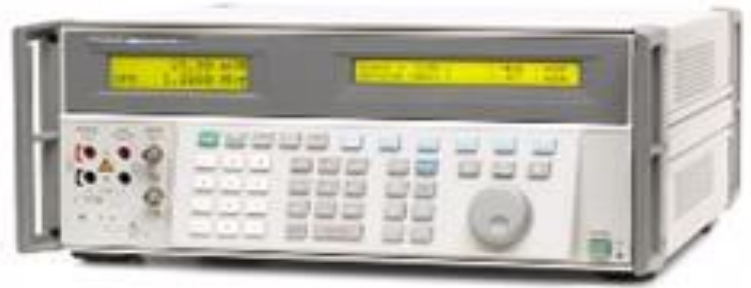

Gambar 2. Multiproduct Calibrator 5500A 
Multiproduct Calibrator 5500A adalah salah satu alat standar yang memiliki akurasi cukup baik. Akurasi hampir semua pengukuran listrik didasarkan pada ketelusuran $d c$ voltage dan resistance. Alat ini termasuk salah satu alat standar yang memiliki kestabilan pengukuran yang cukup baik, kemampuan pengukuran hingga 6.5 digit dibandingkan dengan alat standar lain dikelasnya. ${ }^{(3,12)}$

Tak kalah baiknya dengan alat standar 5500A diatas, kehadiran dari alat standar Multiproduct Calibrator Fluke 5700A seperti yang terlihat pada Gambar 3. Alat standar ini di desain memiliki kemampuan hampir sama dengan apa yang dimiliki oleh 5500A pendahulunya, hanya saja ada sedikit perbedaan pada rentang kapasitas dibeberapa besaran pengukurannya. Hal tersebut bertujuan untuk meningkatkan lagi kemampuan yang dimiliki 5500A dalam menjawab permintaan pelanggan (customer).

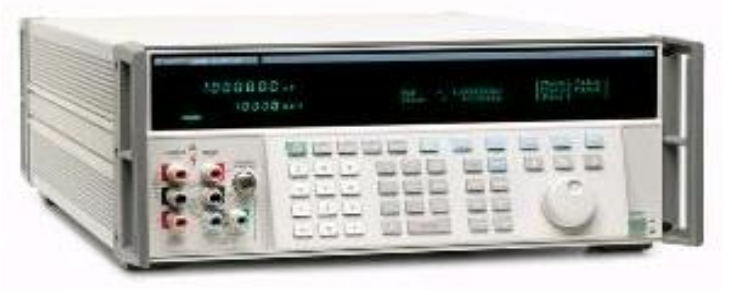

Gambar 3. Multiproduct Calibrator 5700A

\section{METODOLOGI PENELITIAN}

\section{Skema pelaksanaan uji banding}

BBLM telah melaksanakan uji banding independen untuk alat standar Reference Multimeter Fluke 8508A. Uji banding tersebut dilakukan antar ketiga laboratorium kalibrasi yang telah terakreditasi oleh KAN yaitu LK 016 IDN. LK 016 IDN ini terdiri dari 2 (dua) laboratorium dari 3 (tiga) multilokasi yang dimiliki oleh laboratorium kalibrasi Telkom Maintenance Service Center. Lokasinya antara lain : area V Jawa Timur yakni MSC Surabaya (disingkat SBY) dan area III Jawa Barat yakni MSC Cibinong (disingkat CBI), Bersama laboratorium LK 001 IDN yakni laboratorium kalibrasi Balai Besar Logam dan Mesin (BBLM) Bandung. ${ }^{(9)}$

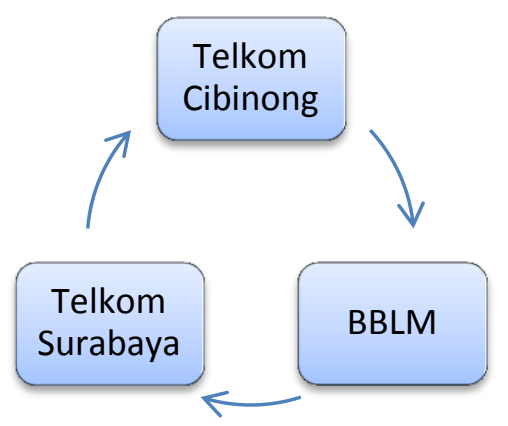

Gambar 4. Skema peserta uji banding

Skema dalam pelaksanaan uji banding, ditetapkannya untuk semua peserta menggunakan Reference Multimeter Fluke 8508A milik masing-masing laboratorium. Kemudian dilakukan proses kalibrasi atau proses pengukuran terhadap Multiproduct Calibrator Fluke 5500A dan 5700 yang berfungsi sebagai referensi pada pelaksanaan uji banding ini seperti yang terlihat pada Gambar 5. ${ }^{(5)}$

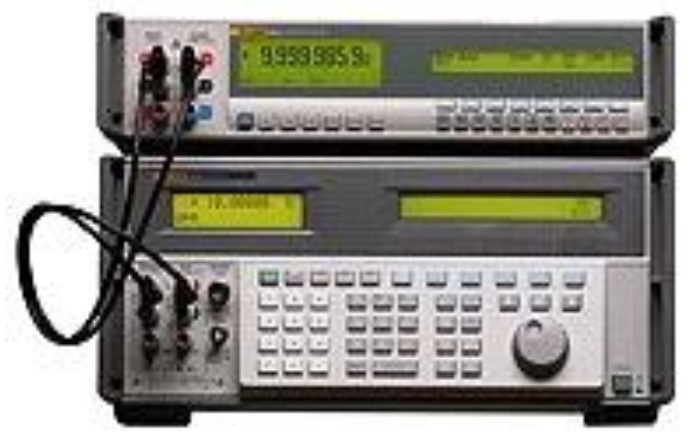

Gambar 5. Proses pengukuran uji banding

Adapun urutan dalam pelaksanaan uji banding yaitu pertama kali dilakukan kalibrasi atau proses pengukuran oleh laboratorium kalibrasi Telkom MSC Surabaya (SBY) yang bertindak sebagai koordinator pelaksana sekaligus sebagai tempat dilaksanakannya uji banding tersebut. Kemudian dilanjutkan oleh laboratorium kalibrasi Telkom MNC Cibinong (CBI) dan terakhir dilanjutkan oleh laboratorium kalibrasi Balai Besar Logam dan Mesin (BBLM).

Adapun beberapa peralatan yang digunakan dalam uji banding tersebut berupa alat standar dan alat yang akan dikalibrasi yang juga 
berfungsi sebagai referensi sumber (source reference). Alat yang digunakan dalam uji banding ini tertera jelas pada tabel penggunaan peralatan dari masing masing laboratorium peserta uji banding secara rinci seperti terlihat pada Tabel 1.

Tabel 1. Peralatan-peralatan uji banding

\begin{tabular}{rccc}
\hline Nama Alat & Merek/Tipe & S/N & Ket \\
\hline $\begin{array}{r}\text { Multiproduct } \\
\text { Calibrator }\end{array}$ & Fluke/5500A & 6495302 & SBY \\
\hline $\begin{array}{r}\text { Multiproduct } \\
\text { Calibrator }\end{array}$ & Fluke/5700A & - & SBY \\
\hline $\begin{array}{r}\text { Reference } \\
\text { Multimeter }\end{array}$ & Fluke/8508A & 166962363 & SBY \\
\hline $\begin{array}{r}\text { Reference } \\
\text { Multimeter }\end{array}$ & Fluke/8508A & 936954140 & CBI \\
\hline $\begin{array}{r}\text { Reference } \\
\text { Multimeter }\end{array}$ & Fluke/8508A & 956655364 & BBLM \\
\hline
\end{tabular}

\section{Pelaksanaan kalibrasi atau pengukuran}

Pelaksanaan kalibrasi atau pengukuran pada uji banding dilakukan oleh ketiga peserta menggunakan alat standar/kalibrator 8508A milik masing-masing peserta. Kalibrasi atau proses pengukuran dilakukan terhadap kedua alat yang digunakan sebagai referensi yaitu 5500A dan 5700A yang telah disediakan oleh koordinator pelaksana yaitu laboratorium Telkom MSC Surabaya.

Proses pelaksanaan uji banding ini dilakukan dengan cara perbandingan langsung. Maksudnya membandingkan secara langsung nilai keluaran dari alat referensi 5500A atau 5700A hasil penginputan nilai yang sesuai dengan nilai pada titik pengukuran dan juga besaran pengukuran yang telah ditetapkan dibandingkan langsung dengan nilai yang terbaca pada alat standar 8508A masingmasing peserta uji banding sesuai dengan urutan pengambilan data. $(1,10,15)$

Adapun prosedur dalam pelaksanaan uji banding ini adalah Pertama, melakukan proses kalibrasi atau pengukuran 5500A menggunakan 8508A disetiap titik pengukuran (Test Point, TP) untuk beberapa besaran pengukuran (measurement) seperti terlihat pada Tabel 2. Titik pengukuran (TP $1, T P 2$, dan TP 3) diambil dengan asumsi linier yang dianggap mewakili rentang pengukuran sesuai yang tertera dalam spesifikasi alat 5500A. ${ }^{(1,15)}$

Tabel 2. Besaran pengukuran dan titik pengukuran

\begin{tabular}{rccr}
\hline Measurement & $T P 1$ & $T P 2$ & $T P 3$ \\
\hline $\begin{array}{r}\text { DC Voltage } \\
\text { AC Voltage } \\
\text { a 60 Hz }\end{array}$ & $100 \mathrm{mV}$ & $10 \mathrm{VV}$ & $700 \mathrm{~V}$ \\
\hline $\begin{array}{r}\text { DC Current } \\
\text { AC Current } \\
\text { (a 60 Hz }\end{array}$ & $100 \mu \mathrm{A}$ & $100 \mathrm{~mA}$ & $10 \mathrm{~A}$ \\
\hline $\begin{array}{r}\text { Resistance } \\
\text { (2wire) }\end{array}$ & $100 \mathrm{~mA}$ & $10 \mathrm{~A}$ \\
\hline $\begin{array}{r}\text { Resistance } \\
\text { (4wire) }\end{array}$ & $10 \Omega$ & $100 \mathrm{~K} \Omega$ & $10 \mathrm{M} \Omega$ \\
\hline & $10 \mathrm{~K} \Omega$ & $100 \mathrm{~K} \Omega$ \\
\hline
\end{tabular}

Kedua, Hasil penunjukan dari 8508A untuk setiap $T P$ dicatat, dengan pengambilan data yang diulang sebanyak 5 kali pengulangan. Ketiga, lakukan hal yang sama untuk 8508A milik peserta lainnya, begitu juga seterusnya. Ulangi langkah pertama sampai ketiga untuk alat referensi yang ke-2 yaitu 5700A. (1,7,15)

Langkah selanjutnya adalah verifikasi data, yaitu proses dilakukan pengambilan data pengukuran pada TP oleh masing-masing peserta, dilakukan pencatatan dimana nilainya akan dimasukkan dalam tabel hasil pengukuran. Dilanjutkan dengan menghitung nilai mean, standar deviasi dan perhitungan nilai angka kesalahan (error number $=E n$ ) pada masing-masing besaran pengukuran. Apabila didapatkan nilai hasil perhitungan ada dalam rentang $-1 \leq E n \leq 1$ maka dapat disimpulkan bahwa 8508A pada titik pengukuran tersebut masih dalam kondisi setara atau inlier, sedangkan apabila nilai hasil perhitungan diluar rentang $-1 \leq E n \leq 1$ maka dianggap tidak setara atau outlier. ${ }^{(8,17,18)}$

Langkah-langkah yang telah dilakukan dan disebutkan pada penjelasan sebelumnya merupakan uraian dari langkah-langkah yang nantinya akan dilakukan oleh semua peserta uji banding untuk alat Reference Multimeter Fluke 8508A yang digunakan sebagai alat standar. 


\section{Nilai acuan uji banding}

Adapun nilai acuan untuk uji banding dapat kita peroleh dengan cara menghitung nilai rata-rata pembobotan (weighted average) dari nilai yang diperoleh semua laboratorium kalibrasi peserta uji banding tersebut dengan menggunakan persamaan (1) dan (2) sebagai berikut: ${ }^{(8,13,14,16,17)}$

$$
\begin{aligned}
& X_{\text {weighted }}=\frac{\sum X_{i} \cdot u_{i}^{-2}}{u_{i}^{-2}} \\
& u_{\text {weighted }}=\frac{1}{\sum u_{i}^{-2}}
\end{aligned}
$$

Keterangan :

$$
\begin{aligned}
X_{\text {weighte }}= & \text { Rata-rata pembobotan dari nilai } \\
& \text { yang diperoleh. } \\
X_{i}= & \text { Nilai yng diperoleh peserta ke- } i \\
u_{i}= & \text { Ketidakpastian yang diperoleh } \\
& \text { laboratorium peserta ke- } i \text { untuk } \\
& \text { nilai } X_{i} \\
u_{\text {weighte }}= & \text { Nilai ketidakpastian dari nilai } \\
& \text { weighted average, } X_{\text {weighted }}
\end{aligned}
$$

Dalam proses pengambilan data hasil pengukuran, ada beberapa cara untuk membuktikan seberapa tepat nilai yang didapat dalam uji banding tersebut. Nilai tersebut haruslah terlebih dahulu dianalisa, untuk melihat seberapa tepat nilai ketidakpastian pengukuran yang diperkirakan dapat menggambarkan sebaran nilai data yang sebenarnya, Hal tersebut dapat dihitung salah satunya menggunakan persamaan Birge_ratio seperti terlihat pada persamaan (3). ${ }^{(8,13,14,16,17)}$

$$
\text { Birge_ratio }=\sqrt{\frac{\sum\left(X_{i}-X_{\text {weighted }}\right)^{2} \cdot u_{i}^{-2}}{(n-1)}} \text { (3) }
$$

Keterangan :

$$
X_{i}=\text { Nilai yang diperoleh peserta }
$$

$$
\begin{aligned}
X_{\text {weighted }}= & \text { Rata-rata pembobotan dari } \\
& \text { nilai yang diperoleh. } \\
& = \\
u_{i} & \text { Ketidakpastian yang diperoleh } \\
& \text { laboratorium peserta ke- } i \\
& \text { untuk nilai } X_{i} \\
= & \text { Jumlah laboratorium peserta } \\
& \text { uji banding }
\end{aligned}
$$

Menurut persamaan Birge ratio, apabila sebaran data nilai $X_{i}$ berada dalam rentang cakupan kesalahan $u_{i}$ pada data tersebut, maka nilai Birge ratio akan kurang dari 1 dan apabila sebaran data lebih besar, nilai Birge_ratio akan lebih besar dari $1 .^{(6,8,17)}$

Dalam penggunaan persamaan Birge ratio diatas, penggunaan persamaan kriteria statistik dapat dilakukan untuk menetapkan kebenaran dari nilai Birge_ratio yang didapat. Nilai Birge_ratio yang didapat akan dianggap baik (sebaran data berada dalam cakupan rentang kesalahannya) apabila nilainya lebih kecil dari nilai Birge_Criterion seperti tertera pada persamaan $(4){ }^{(6,8,17)}$

Birge_criterion $<\sqrt{1+\sqrt{\frac{8}{(n-1)}}} \ldots(4)$

keterangan :

$\mathrm{n}=$ Jumlah lab. peserta uji banding

\section{Menentukan penyimpangan nilai acuan}

Dilakukannya identifikasi peyimpangan signifikan yang terjadi diantara laboratorium peserta uji banding sesuai dengan salah satu persyaratan dokumen dari Mutual Recognition Arrangement (MRA-Appendix F). Langkahlangkah yang akan dilakukan selanjutnya adalah menghitung nlai En seperti persamaan (5) berikut ini: ${ }^{(2,6,8,17)}$

$$
E_{n}=\frac{\left(X_{\text {lab }, i}-X_{\text {weighted }}\right)}{\sqrt{U_{l a b, i}^{2}+U_{\text {weghted }}^{2}}} \ldots \ldots \ldots
$$




$$
\begin{aligned}
X_{\text {lab. } i}= & \begin{array}{l}
\text { Nilai yang diperoleh lab. peserta } \\
\text { pada titik ukur i. }
\end{array} \\
X_{\text {weighted }}= & \begin{array}{l}
\text { Rata-rata pembobotan } \\
\text { (weighted average) dari nilai }
\end{array} \\
& \begin{array}{l}
\text { yang diperoleh } \\
\text { Ketidakpastian yang diperoleh } \\
\text { oleh lab. pada titik ukur i. }
\end{array} \\
u_{\text {lab. } i} & \text { Nilai ketidakpastian dari nilai } \\
& \text { weighted average, } X_{\text {weighted }}
\end{aligned}
$$

Nilai yang didapat semua peserta pada titik ukur akan dianggap menyimpang secara signifikan atau tidak setara (outlier) apabila nilai $E n$ untuk titik $i$ tersebut nilainya lebih kecil dari -1 dan lebih besar dari $1 .{ }^{(8,17)}$

\section{HASIL DAN PEMBAHASAN}

Berikut ini adalah data hasil perhitungan nilai angka kesalahan (En) untuk semua laboratorium kalibrasi sebagai peserta uji banding untuk 6 (Enam) besaran pengukuran (measurement). Masing-masing besaran terdiri dari 3 (Tiga) titik pengukuran $(T P)$. Pengambilan data pengukuran Reference Multimeter Fluke 8508A menggunakan 2 alat referensi Multiproduct Calibrator Fluke 5500A dan 5700A (diberi tanda*) dapat terlihat dengan jelas pada Tabel $3 \mathrm{~s} / \mathrm{d}$ Tabel 8 .

Tabel 3. Nilai En peserta uji banding pada besaran pengukuran $D C$ Voltage

\begin{tabular}{rlll}
\hline \multirow{2}{*}{$\begin{array}{c}\text { Test } \\
\text { Point }\end{array}$} & \multicolumn{3}{c}{$-1 \leq$ En $\leq \mathbf{1}$} \\
\cline { 2 - 4 } & SBY & CBI & BBLM \\
\hline \multirow{2}{*}{$100 \mathrm{mV}$} & 0.01 & -0.01 & 0.00 \\
\cline { 2 - 4 } & $-0.02 *$ & $0.00 *$ & $0.02 *$ \\
\hline \multirow{2}{*}{$10 \mathrm{~V}$} & 0.00 & 0.00 & 0.00 \\
\cline { 2 - 4 } & $0.00 *$ & $0.00 *$ & $0.00 *$ \\
\hline \multirow{2}{*}{$700 \mathrm{~V}$} & 0.09 & -0.25 & 0.16 \\
\cline { 2 - 4 } & $0.01 *$ & $-0.01 *$ & $0.00 *$ \\
\hline * Multiproduct Calibrator 5700A
\end{tabular}

Tabel 3 merupakan hasil pengukuran menggunakan alat referensi 5500A untuk titik pengukuran $100 \mathrm{mV}$, didapatkan nilai $E n$ oleh SBY sebesar 0.01, CBI sebesar -0.01 dan BBLM sebesar 0.00 , sedangkan pada alat referensi 5700A, nilai En oleh SBY sebesar -0.02, CBI sebesar 0.00 dan BBLM sebesar 0.02 . Kesemua nilai tersebut berada didalam nilai $-1 \leq E n \leq 1$. Nilai $E n$ yang setara juga didapatkan pada semua peserta pada titik pengukuran $10 \mathrm{~V}$ dan $700 \mathrm{~V}$ untuk pengukuran DC Voltage.

Tabel 4. Nilai En peserta uji banding pada besaran pengukuran $A C$ Voltage (60 $\mathrm{Hz}$ )

\begin{tabular}{llll}
\hline \multirow{2}{*}{$\begin{array}{c}\text { Test } \\
\text { Point }\end{array}$} & \multicolumn{3}{c}{$-1 \leq$ En $\leq \mathbf{1}$} \\
\cline { 2 - 4 } & SBY & CBI & BBLM \\
\hline \multirow{2}{*}{$100 \mathrm{mV}$} & 0.00 & -0.05 & 0.050 \\
\cline { 2 - 4 } & $0.03 *$ & $-0.02 *$ & $-0.02 *$ \\
\hline \multirow{2}{*}{$10 \mathrm{~V}$} & 0.00 & 0.00 & 0.00 \\
\cline { 2 - 4 } & $0.00 *$ & $0.00 *$ & $0.00 *$ \\
\hline \multirow{2}{*}{$700 \mathrm{~V}$} & 0.03 & -0.06 & 0.03 \\
\cline { 2 - 4 } & $0.01 *$ & $-0.05 *$ & $0.05 *$ \\
\hline \multirow{2}{*}{ Multiproduct Calibrator 5700A }
\end{tabular}

Tabel 4 merupakan hasil pengukuran menggunakan alat referensi 5500A untuk titik pengukuran $100 \mathrm{mV}$, didapatkan nilai $E n$ oleh SBY sebesar 0.01, CBI sebesar -0.01 dan BBLM sebesar 0.00 , sedangkan pada alat referensi 5700A, nilai En oleh SBY sebesar -0.02, CBI sebesar 0.00 dan BBLM sebesar 0.02 . Kesemua nilai tersebut berada didalam nilai $-1 \leq E n \leq 1$. Nilai $E n$ yang setara juga didapatkan pada semua peserta pada titik pengukuran $10 \mathrm{~V}$ dan $700 \mathrm{~V}$ untuk pengukuran AC Voltage $(60 \mathrm{~Hz})$.

Tabel 5. Nilai En peserta uji banding pada besaran pengukuran DC Current

\begin{tabular}{llll}
\hline \multirow{2}{*}{$\begin{array}{c}\text { Test } \\
\text { Point }\end{array}$} & \multicolumn{3}{c}{$-1 \leq$ En $\leq 1$} \\
\cline { 2 - 4 } & SBY & CBI & BBLM \\
\hline \multirow{2}{*}{$100 \mu \mathrm{A}$} & 0.00 & -0.05 & 0.05 \\
\cline { 2 - 4 } & $0.01 *$ & $-0.02 *$ & $-0.02 *$ \\
\hline \multirow{2}{*}{$100 \mathrm{~mA}$} & 0.00 & 0.00 & 0.00 \\
\cline { 2 - 4 } & $0.01 *$ & $-0.01 *$ & $0.00 *$ \\
\hline \multirow{2}{*}{$10 \mathrm{~A}$} & 0.00 & 0.00 & 0.03 \\
\cline { 2 - 4 } & $0.00 *$ & $0.00 *$ & $0.05 *$ \\
\hline
\end{tabular}

* Multiproduct Calibrator 5700A

Tabel 5 merupakan hasil pengukuran menggunakan alat referensi 5500A untuk titik pengukuran $100 \mu \mathrm{A}$, didapatkan nilai $E n$ oleh SBY sebesar 0.00, CBI sebesar -0.05 dan BBLM sebesar 0.05, sedangkan pada alat referensi 5700A, nilai En oleh SBY sebesar 0.01 , CBI sebesar -0.02 dan BBLM sebesar -0.02. Kesemua nilai tersebut berada didalam nilai $-1 \leq E n \leq 1$. Nilai $E n$ yang setara juga didapatkan pada semua peserta pada titik 
pengukuran $100 \mathrm{~mA}$ dan $10 \mathrm{~A}$ untuk pengukuran DC Current.

Tabel 6. Nilai En peserta uji banding pada besaran pengukuran AC Current (60 $\mathrm{Hz})$

\begin{tabular}{llll}
\hline \multirow{2}{*}{$\begin{array}{c}\text { Test } \\
\text { Point }\end{array}$} & \multicolumn{3}{c}{$-1 \leq$ En $\leq \mathbf{1}$} \\
\cline { 2 - 4 } & SBY & CBI & BBLM \\
\hline \multirow{2}{*}{$100 \mu \mathrm{AA}$} & 0.26 & -0.12 & -0.14 \\
\cline { 2 - 4 } & $0.02 *$ & $-0.02 *$ & $0.00 *$ \\
\hline \multirow{2}{*}{$100 \mathrm{~mA}$} & 0.01 & -0.01 & 0.00 \\
\cline { 2 - 4 } & $0.02 *$ & $-0.02 *$ & $-0.01 *$ \\
\hline \multirow{2}{*}{$10 \mathrm{~A}$} & 0.00 & 0.00 & 0.00 \\
\cline { 2 - 4 } & $0.00 *$ & $0.00 *$ & $0.00 *$ \\
\hline * Multiproduct Calibrator $5700 \mathrm{~A}$ &
\end{tabular}

Tabel 6 merupakan hasil pengukuran menggunakan alat referensi 5500A untuk titik pengukuran $100 \mu \mathrm{A}$, didapatkan nilai En oleh SBY sebesar 0.26, CBI sebesar -0.12 dan BBLM sebesar -0.14 , sedangkan pada alat referensi 5700A, nilai $E n$ oleh SBY sebesar 0.02, CBI sebesar -0.02 dan BBLM sebesar 0.00 . Kesemua nilai tersebut berada didalam nilai $-1 \leq E n \leq 1$. Nilai $E n$ yang setara juga didapatkan pada semua peserta pada titik pengukuran $100 \mathrm{~mA}$ dan $10 \mathrm{~A}$ untuk pengukuran AC Current $(60 \mathrm{~Hz})$.

Tabel 7. Nilai En peserta uji banding pada besaran pengukuran Resistance ( 2 wire)

\begin{tabular}{rlll}
\hline \multirow{2}{*}{$\begin{array}{c}\text { Test } \\
\text { Point }\end{array}$} & \multicolumn{3}{c}{$-1 \leq$ En $\leq 1$} \\
\cline { 2 - 4 } & SBY & CBI & BBLM \\
\hline \multirow{2}{*}{$1 \Omega$} & 0.00 & 0.13 & -0.13 \\
\cline { 2 - 4 } & $0.26 *$ & $-0.27 *$ & $0.01 *$ \\
\hline \multirow{2}{*}{$100 \mathrm{~K} \Omega$} & 0.00 & 0.00 & 0.00 \\
\cline { 2 - 4 } & $0.00 *$ & $-0.01 *$ & $0.00 *$ \\
\hline \multirow{2}{*}{$100 \mathrm{M} \Omega$} & 0.00 & 0.00 & 0.00 \\
\cline { 2 - 4 } & $0.00 *$ & $0.00 *$ & $0.00 *$ \\
\hline
\end{tabular}

* Multiproduct Calibrator $5700 \mathrm{~A}$

Tabel 7 merupakan hasil pengukuran menggunakan alat referensi 5500A untuk titik pengukuran $1 \Omega$, didapatkan nilai $E n$ oleh SBY sebesar 0.00, CBI sebesar 0.13 dan BBLM sebesar -0.13 , sedangkan pada alat referensi 5700A, nilai $E n$ oleh SBY sebesar 0.26 , CBI sebesar -0.27 dan BBLM sebesar 0.01 . Kesemua nilai tersebut berada didalam nilai $-1 \leq E n \leq 1$. Nilai $E n$ yang setara juga didapatkan pada semua peserta pada titik pengukuran $100 \mathrm{~K} \Omega$ dan $100 \mathrm{M} \Omega$ untuk pengukuran resistance (2 wire).

Tabel 8. Nilai En peserta uji banding pada besaran pengukuran Resistance (4 wire)

\begin{tabular}{llll}
\hline \multirow{2}{*}{$\begin{array}{c}\text { Test } \\
\text { Point }\end{array}$} & \multicolumn{3}{c}{$-1 \leq \mathbf{E n} \leq \mathbf{1}$} \\
\cline { 2 - 4 } & SBY & CBI & BBLM \\
\hline \multirow{2}{*}{$10 \Omega$} & -0.02 & 0.02 & 0.00 \\
\cline { 2 - 4 } & $-96.99 *$ & $96.99 *$ & $0.00 *$ \\
\hline \multirow{2}{*}{$1 \mathrm{~K} \Omega$} & 0.00 & 0.00 & 0.00 \\
\cline { 2 - 4 } & $0.00 *$ & $0.00 *$ & $0.00 *$ \\
\hline \multirow{2}{*}{$100 \mathrm{~K} \Omega$} & 0.00 & -0.02 & 0.02 \\
\cline { 2 - 4 } & $0.01 *$ & $-0.01 *$ & $0.00 *$ \\
\hline \multirow{2}{*}{ Non }
\end{tabular}

* Multiproduct Calibrator $5700 \mathrm{~A}$

Tabel 8 merupakan hasil pengukuran menggunakan alat referensi 5500A untuk titik pengukuran $10 \Omega$, didapatkan nilai $E n$ oleh SBY sebesar -0.02, CBI sebesar 0.02 dan BBLM sebesar 0.00, Kesemua nilai tersebut berada didalam nilai $-1 \leq E n \leq 1$, sedangkan pada alat referensi 5700A, nilai En oleh SBY sebesar -96.99, CBI sebesar 96.99 dan BBLM sebesar 0.00, Nilai yang didapat oleh SBY dan CBI tidak setara karena berada diluar nilai $-1 \leq E n \leq 1$ atau outlier tetapi BBLM nilainya setara. Nilai En yang setara juga didapatkan pada semua peserta pada titik pengukuran $100 \mathrm{~K} \Omega$ dan $100 \mathrm{M} \Omega$ untuk resistance (4 wire).

Berdasarkan dari hasil perhitungan yang didapat, nilai angka kesalahan (En) dari ketiga laboratorium kalibrasi peserta uji banding terlihat di Tabel 3 sampai Tabel 8. Kemudian dilakukan perbandingan atau interkomparasi nilai diantara ketiga laboratorium tersebut sehingga didapatkan 3 kali perbandingan seperti terlihat pada Tabel 9.

Perbandingan Pertama, dibandingkan nilai En antara laboratorium SBY dengan laboratorium CBI. Kedua, laboratorium CBI dibandingkan dengan laboratorium BBLM. Ketiga adalah perbandingan nilai $E n$ antara laboratorium BBLM dengan laboratorium SBY. Sebagai ilustrasi ketiga skema tersebut, yaitu perbandingan antara SBY terhadap CBI ; dituliskan SBY $><\mathrm{CBI}$, perbandingan $\mathrm{CBI}$ terhadap BBLM ; dituliskan CBI $><$ BBLM dan terakhir, perbandingan BBLM terhadap SBY ; dapat pula dituliskan BBLM $><$ SBY sebagaimana pula terlihat pada Tabel 9. 
Mengacu dari persamaan (5) yang telah disebutkan sebelumnya, apabila nilai angka kesalahan (error number $=E n$ ) yang didapat dari hasil perhitungannya sebelumnya sebesar $-1 \leq E n \leq 1$, maka dapat disimpulkan bahwa 8508A pada titik pengukuran dari semua besaran pengukuran tersebut masih dalam kondisi setara, dan apabila nilai En diluar dari pada $-1 \leq E n \leq 1$ maka hasilnya disimpulkan tidak setara.
Tabel 9 menunjukkan perbandingan nilai angka kesalahan (En) tidak setara/outlier antara SBY $><\mathrm{CBI}$ dan juga $\mathrm{CBI}><\mathrm{BBLM}$ di titik pengukuran (Test Poin, TP) $10 \Omega$ pada besaran pengukuran resistance 4 wire yang menggunakan alat referensi 5700A karena nilai SBY sebesar -96.99 dan CBI sebesar 96.99 berada diluar nilai $-1 \leq E n \leq 1$ sedangkan nilai BBLM sebesar 0.00.

Tabel 9. Perbandingan nilai angka kesalahan (error number $=E n$ ) peserta uji banding untuk Reference Multimeter 8508A terhadap Multiproduct Calibrator 5500A dan 5700A

\begin{tabular}{|c|c|c|c|c|c|c|}
\hline \multirow{2}{*}{ No. } & \multirow{2}{*}{$\begin{array}{r}\text { Test } \\
\text { Point }\end{array}$} & \multicolumn{3}{|c|}{$-1 \leq E_{n} \leq 1$} & \multirow{2}{*}{ Ref. } & \multirow{2}{*}{ Measurement } \\
\hline & & $(\mathrm{SBY} \gg \mathrm{CBI})$ & $(C B I \rightleftharpoons B B I M)$ & $(B B L M=\infty S B Y)$ & & \\
\hline \multirow{2}{*}{1.} & \multirow{2}{*}{$100 \mathrm{mV}$} & Setara & Setara & Setara & $5500 \mathrm{~A}$ & \multirow{6}{*}{ DCVoltage } \\
\hline & & Setara & Setara & Setara & $5700 \mathrm{~A}$ & \\
\hline \multirow{2}{*}{2.} & \multirow{2}{*}{$10 \mathrm{~V}$} & Setara & Setara & Setara & $5500 \mathrm{~A}$ & \\
\hline & & Setara & Setara & Setara & $5700 \mathrm{~A}$ & \\
\hline \multirow[b]{2}{*}{3.} & \multirow{2}{*}{$700 \mathrm{~V}$} & Setara & Setara & Setara & $5500 \mathrm{~A}$ & \\
\hline & & Setara & Setara & Setara & $5700 \mathrm{~A}$ & \\
\hline \multirow{2}{*}{4.} & \multirow{2}{*}{$100 \mathrm{mV}$} & Setara & Setara & Setara & $5500 \mathrm{~A}$ & \multirow{6}{*}{$\begin{array}{r}\text { ACVoltage } \\
60 \mathrm{~Hz}\end{array}$} \\
\hline & & Setara & Setara & Setara & $5700 \mathrm{~A}$ & \\
\hline \multirow{2}{*}{5.} & \multirow{2}{*}{$10 \mathrm{~V}$} & Setara & Setara & Setara & $5500 \mathrm{~A}$ & \\
\hline & & Setara & Setara & Setara & $5700 \mathrm{~A}$ & \\
\hline \multirow{2}{*}{6.} & \multirow{2}{*}{$700 \mathrm{~V}$} & Setara & Setara & Setara & $5500 \mathrm{~A}$ & \\
\hline & & Setara & Setara & Setara & $5700 \mathrm{~A}$ & \\
\hline \multirow{2}{*}{7.} & \multirow[b]{2}{*}{$100 \mathrm{HA}$} & Setara & Setara & Setara & $5500 \mathrm{~A}$ & \multirow{6}{*}{ DCCurvent } \\
\hline & & Setara & Setara & Setara & $5700 \mathrm{~A}$ & \\
\hline \multirow{2}{*}{8.} & \multirow{2}{*}{$100 \mathrm{~mA}$} & Setara & Setara & Setara & $5500 \mathrm{~A}$ & \\
\hline & & Setara & Setara & Setara & $5700 \mathrm{~A}$ & \\
\hline \multirow{2}{*}{9.} & \multirow{2}{*}{$10 \mathrm{~A}$} & Setara & Setara & Setara & $5500 \mathrm{~A}$ & \\
\hline & & Setara & Setara & Setara & $5700 \mathrm{~A}$ & \\
\hline \multirow{2}{*}{10} & & Setara & Setara & Setara & $5500 \mathrm{~A}$ & \\
\hline & 100 HA & Setara & Setara & Setara & $5700 \mathrm{~A}$ & \\
\hline & & Setara & Setara & Setara & $5500 \mathrm{~A}$ & AC Current \\
\hline 11. & $100 \mathrm{~m} \cdot \mathrm{A}$ & Setara & Setara & Setara & $5700 \mathrm{~A}$ & $60 \mathrm{~Hz}$ \\
\hline 12 & & Setara & Setara & Setara & $5500 \mathrm{~A}$ & \\
\hline 12. & $10 \mathrm{~A}$ & Setara & Setara & Setara & $5700 \mathrm{~A}$ & \\
\hline $7=$ & 10 & Setara & Setara & Setara & $5500 \mathrm{~A}$ & \\
\hline 13. & 132 & Setara & Setara & Setara & $5700 \mathrm{~A}$ & \\
\hline 144 & $100 \mathrm{KO}$ & Setara & Setara & Setara & $5500 \mathrm{~A}$ & Resistance \\
\hline 14. & $100 \mathrm{k} \Omega 2$ & Setara & Setara & Setara & $5700 \mathrm{~A}$ & 2 wire \\
\hline & & Setara & Setara & Setara & $5500 \mathrm{~A}$ & \\
\hline 15. & $100 \mathrm{~N} 1 \mathrm{~s}$ & Setara & Setara & Setara & $5700 \mathrm{~A}$ & \\
\hline & & Setara & Setara & Setara & $5500 \mathrm{~A}$ & \\
\hline 16. & $10 \Omega$ & Tidial: Setara & Tidial Setara & Setara & $5700 \mathrm{~A}$ & \\
\hline & & Setara & Setara & Setara & $5500 \mathrm{~A}$ & Resistance \\
\hline 17. & $1 \mathrm{k} \Omega$ & Setara & Setara & Setara & $5700 \mathrm{~A}$ & 4 wire \\
\hline 18 & $100 \mathrm{KO}$ & Setara & Setara & Setara & $5500 \mathrm{~A}$ & \\
\hline 18. & $100 \mathrm{Kus}$ & Setara & Setara & Setara & $5700 \mathrm{~A}$ & \\
\hline
\end{tabular}

\section{KESIMPULAN DAN SARAN}

\section{KESIMPULAN}

Proses uji banding antar laboratorium telah selesai dilakukan dengan hasil yang memuaskan. Hal tersebut dapat terlihat jelas dari data hasil perbandingan ketiga peserta uji banding dengan perbandingan perhitungan nilai angka kesalahan $($ error number $=E n)$ dalam rentang $-1 \leq \mathrm{En} \leq 1$ untuk keseluruhan besaran dan titik pengukuran kecuali pada besaran pengukuran resistance 4 wire $\mathrm{di}$ titik pengukuran $10 \Omega$ di referensi $5700 \mathrm{~A}$ pada Telkom MSC Surabaya (SBY) sebesar $-96,99$ dan MSC Cibinong (CBI) sebesar 96,99.

Bahwa laboratorium kalibrasi Balai Besar Logam dan Mesin (BBLM) Bandung khususnya pada laboratorium kelistrikan sudah mampu melaksanakan kalibrasi Multiproduct Calibrator Fluke 5500A dan 5700A menggunakan alat standar atau kalibrator utama 
BBLM berupa Reference Multimeter Fluke 8508A sehingga dapat meningkatkan unjuk kerja laboratorium dalam penggunaan metoda analisis dalam menjamin mutu hasil kalibrasi.

Data hasil uji banding dapat digunakan untuk memenuhi salah satu syarat audit kecukupan dalam pengajuan re-akreditasi laboratorium.

\section{SARAN}

Dikarenakan pelaksanaan uji banding antar laboratorium secara independen ini baru pertama kali dilaksanakan secara baik dan terkoordinir khususnya BBLM, agar kiranya kegiatan serupa perlu terus dilanjutkan secara berkala dan juga untuk kalibrator lainnya dengan harapan laboratorium akan tetap terjaga konsistensinya dalam menjamin mutu hasil laboratorium kalibrasi.

\section{UCAPAN TERIMA KASIH}

Penulis mengucapkan terima kasih yang sebesar-besarnya kepada semua pihak khususnya Bapak Ir. Enuh Rosdeni, M.Eng, Bapak DR. Sri Bimo Pratomo, ST.,M.Eng., Bapak Ir. Mustansir, MT., dan juga Ibu Dra. Sulismiati, MM. yang telah banyak memberikan motivasi, support dan sumbangan pikirannya serta semua pihak pada umumnya yang telah membantu dalam penelitian ini.

\section{DAFTAR PUSTAKA}

1. BBLM. Instruksi kerja laboratorium kelistrikan BBLM IK-16-KL-18. Laboratorium Kalibrasi. Bandung.

2. BSN. 2008. SNI ISO/IEC 17025:2008 Persyaratan Umum Kompetensi Laboratorium Pengujian dan Laboratorium Kalibrasi. Jakarta.

3. FLUKE. 2007. Using Reference Multimeters For Precision Measurements: Replacing Analog Null Detectors With Reference Multimeters. MET-302. Amerika.

4. FLUKE. 2012. 8508A Digital Reference Multimeter Users Manual. Rev. 2, 5/03

5. Fuji, Katsumi. et al. 2016. 2-3 Calibration of Standard Voltage and Current Generator. Vol 63 No. 1. Journal of
National Institut of Information and Communication Technology. Japan

6. ISO/IEC 17043 : 2008 Conformity Assessment-General Requiremnts For Proficiency Testing.

7. ISO/IEC/ Guide 98-3:2008. Uncertainty Of Measurement- Part 3: Guide To The Expression of Uncertainty In Measurement.

8. ISO 13528:2005 Statistical Methods By Interlaboratory Comparisons.

9. KAN. 2014. Sertifikat Akreditasi Laboratorium Kalibrasi LK-001 IDN. Jakarta.

10. KAN. 2004. KAN Guide on Measurement Assurence. DP.01.33 (E). Jakarta.

11. Manual Book. (2012). 8508A Reference Multimeter Extended Specifications, Fluke Corporation.

12. MIKES METROLOGY. 2016. Calibration Service: International Competitiveness and Reliability. Finland. $\mathrm{P}: 24-41$.

13. N. Siddique, S. Waheed. Y. Faiz. 2012. Critical Evaluation Of Laboratory Performance From IAEA - 452 (Fish Scallop) Inter-Comparison Exercise Results. No.291. Hungary. Journal of Radioanalytical and Nuclear Chemistry. P: 919-926.

14. Santoso, Budi.,et al. 2015. Uji Banding Laboratorium BMKG. Jakarta.

15. War, Cak. Hadi, Anwar. 2014. Uji Banding Laboratorium Berdasarkan SNI ISO/IEC 17043:2010 \& ISO/IEC 13528:2005. Jakarta.

16. Yusuf, Saeful. Rukihati. Kuntoro, Iman. 2011. Evaluasi Uji Banding Antar Laboratorium AAN Terhadap Cuplikan Lingkungan. Tanggerang. BATAN.

17. Zaid, Ghufron. 2011. Analisa Hasil Uji Banding Antar Laboratorium Nasional Tingkat Asia Pasifik Untuk Termometer Cairan Dalam Gelas, Vol. 13. Jakarta. Jurnal Standardisasi. P:184 - 191.

18. Zhao, Huaying. et al. $2015 . \quad A$ Multilaboratory Comparison of Calibration Accuracy and the Performance of External References in Analytical Ultracentrifugation. PLoS ONE Journal 10 (5). German. 